\title{
Chief Information Officer (CIO) dan Peranannya di Dalam Penyelarasan Strategi Bisnis dan Strategi Teknologi Informasi
}

\author{
Darmawan Setiya Budi \\ Magister Teknik Informatika \\ STIMIK Amikom \\ darmawan.setiyabudi@gmail.com
}

\author{
Heri Abijono \\ Magister Teknik Informatika \\ STIMIK Amikom \\ ahabijono@gmail.com
}

\begin{abstract}
Abstrak - Sebuah penelitian memperkirakan belanja teknologi informasi di seluruh dunia sampai dengan akhir tahun 2016, diperkirakan mencapai USD 2,4 triliun dan akan mencapai USD 2,7 triliun pada tahun 2020. Sayangnya dengan belanja yang tersebut, investasi TI seringkali tidak memberikan manfaat sesuai yang diharapkan organisasi, karena investasi hanya fokus pada aspek teknologi dan kurangnya pemahaman bagaimana teknologi dapat mendukung organisasi, baik dari dari sisi strategis ataupun operasional. Untuk memastikan strategi TI dengan strategi bisnis dapat berjalan selaras, diperlukan pemimpin yang mampu dan memiliki kompetensi yang tepat untuk mengelola TI suatu entitas bisnis atau organisasi. Pemimpin ini harus memiliki kualifikasi di bidang manajerial dan teknologi. Figur pemimpin ini dikenal dengan Chief Information Officer (CIO).

Kata Kunci : chief information officer, CIO, strategi bisnis, strategi TI, keselarasan bisnis dan TI.
\end{abstract}

\section{PENDAHULUAN}

Hasil penelitian lembaga riset International Data Corporation (IDC) memperkirakan bahwa belanja teknologi informasi di seluruh dunia sampai dengan akhir tahun 2016, diperkirakan mencapai USD 2,4 triliun dan akan mencapai USD 2,7 triliun pada tahun 2020. Peningkatan tersebut disebabkan bahwa TI diposisikan sebagai aset perusahaan untuk menghadapi persaingan yang semakin ketat dan terbuka [1]. Berbagai perangkat keras, perangkat lunak dan layanan TI merupakan komponen dari belanja TI yang sedemikian besar. Sayangnya dengan belanja yang tersebut, investasi TI seringkali tidak memberikan manfaat sesuai yang diharapkan organisasi, karena investasi hanya fokus pada aspek teknologi dan kurangnya pemahaman bagaimana teknologi dapat mendukung organisasi, baik dari dari sisi strategis ataupun operasional [2].

Dan dalam menentukan strategi TI yang tepat, guna mendukung pencapaian visi dan misi bisnis, diperlukan pemahaman secara utuh tentang strategi bisnis. Pemahaman tersebut terkait dengan mengapa bisnis dijalankan, tujuan dan arah bisnis, kapan dan bagaimana mencapai tujuan bisnis, serta perubahan yang perlu dan harus dilakukan. Sehingga, penyelarasan strategi TI dengan strategi bisnis, merupakan hal yang utama dan fokus dalam membangun strategi TI. Keunggulan TI yang dipergunakan dan dikelola dengan benar dan selaras dengan tujuan bisnis, dipastikan akan bisa memberikan nilai kepada bisnis [3]. Ketidakselarasan strategi bisnis dan TI menyebabkan kegagalan dan kehilangan peluang bagi bisnis.

Untuk memastikan strategi TI dengan strategi bisnis dapat berjalan selaras, diperlukan pemimpin yang mampu dan memiliki kompetensi yang tepat untuk mengelola TI suatu entitas bisnis atau organisasi. Pemimpin ini harus memiliki kualifikasi di bidang manajerial dan teknologi. Figur pemimpin ini dikenal dengan Chief Information Officer (CIO).

\section{KAJIAN PUSTAKA}

\section{A. Penyelarasan Strategi Bisnis dan TI}

Penyelarasan strategi bisnis dan TI merupakan hal utama yang menjadi perhatian manajemen TI. Mengacu kepada hasil penelitian pada tabel 1, penyelarasan bisnis dari TI selalu berada dalam sepuluh besar hal yang menjadi perhatian utama sejak tahun 1984 Error! Reference source not found.. Hal ini mengindikasikan bahwa penyelarasan strategi bisnis dan TI menjadi sesuatu yang sangat serius dan penting untuk dilakukan, jika tidak boleh dibilang sebagai sesuatu yang harus dilakukan.

Definisi penyelarasan adalah penerapan sistem TI di waktu dan cara yang tepat dan harmonis dengan strategi, tujuan dan kebutuhan bisnis [5]. Selain itu, organisasi perlu membangun, menyelaraskan dan mengembangkan keunggulan kompetitif melalui pemberdayaan SI/TI untuk menjawab tantangan kompetisi global [2]. 


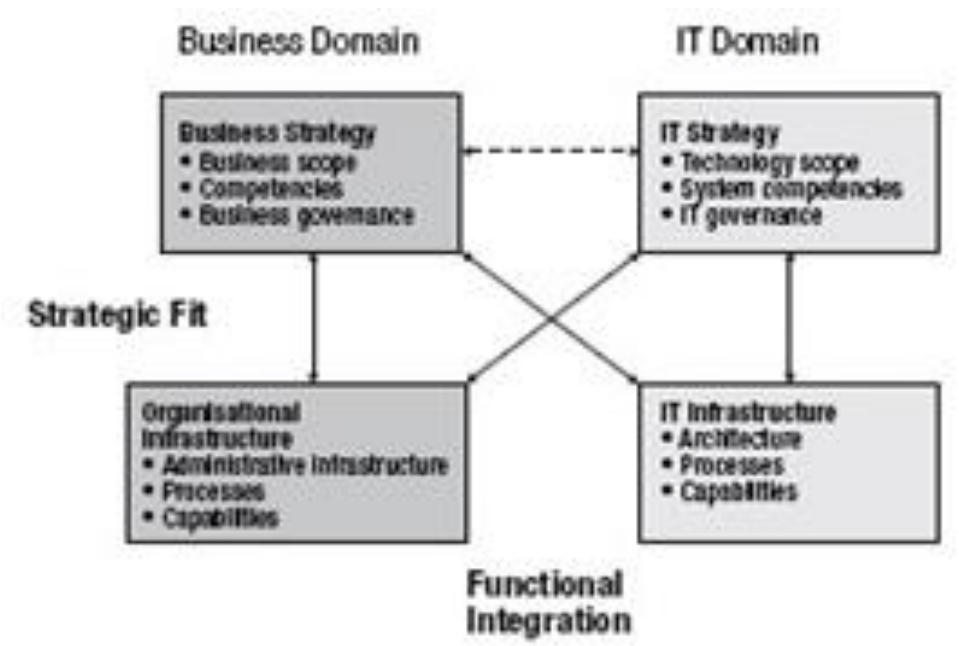

Gambar 1. Strategic Alignment Model.

Tabel 1. Sepuluh Peringkat Teratas Perhatian Manajemen TI.

\begin{tabular}{|c|c|c|c|c|c|c|c|c|c|c|c|c|}
\hline IT Management Concerns/Issues & $\frac{ \pm}{\bar{\nabla}}$ & $\stackrel{m}{\bar{N}}$ & 곡 & $\overline{\bar{\sim}}$ & 을 & હે & ஜ̊̊ి & હે & §̊ & ஜ̊. & ঙ্ণ & હે̊ి \\
\hline Alignment of IT with the Business & 1 & 1 & 2 & 1 & 3 & 2 & 1 & 2 & 1 & 1 & 1 & 1 \\
\hline Security/Privacy & 2 & 7 & 9 & 8 & 9 & 9 & 8 & 6 & 3 & 2 & 3 & 3 \\
\hline Business Agility/Flexibility & 3 & 2 & 3 & 2 & 2 & 3 & 13 & 17 & 7 & & 5 & 7 \\
\hline Business Productivity & 4 & 3 & 1 & 4 & 1 & 1 & 7 & 4 & & & & \\
\hline IT Time-to-Market/Speed of IT Delivery & 5 & & & & & & & & & & & \\
\hline IT Value Proposition in the Business & 6 & & & & & & & & & & & \\
\hline Velocity of Change in the Business & 7 & & & & & & & & & & & \\
\hline Innovation & 8 & & & & & & & & & & & \\
\hline Business Cost Reduction/Controls & 9 & 4 & & & & & & & & & & \\
\hline Revenue Generating IT Projects & 10 & 10 & 4 & 9 & 6 & 8 & 17 & & & & & \\
\hline
\end{tabular}

Dalam Strategic Alignment Model (SAM), digambarkan keselarasan strategi bisnis dan TI dalam sebuah model. SAM terdiri dari empat kuadran dan setiap kuadran terdiri dari tiga komponen, sesuai gambar 1. Keempat kuadran tersebut yaitu: strategi bisnis, strategi TI, infrastruktur organisasi dan infrastruktur TI. SAM menggambarkan keterkaitan antara empat domain yang terdapat di dalamnya. Keterkaitan secara vertikal disebut dengan kesesuaian strategi (strategic fit). Sedangkan keterkaitan secara horizontal disebut dengan integrasi fungsional (functional integration).

Sedangkan model pengembangan dari SAM adalah Strategic Alignment Maturity Model (SAMM). SAMM merupakan framework yang diperkenalkan oleh Jerry Luftman [6] yang berguna untuk mengukur tingkat kematangan (maturity level) dari keselarasan bisnis dan TI yang terdiri dari enam komponen, sesuai gambar 2.

Pengukuran tiap kriteria dalam komponen SAMM akan menghasilkan nilai rerata 1 (satu) hingga 5 (lima) dalam skala Likert. Nilai tersebut mencerminkan tingkat kematangan suatu bisnis atau organisasi terkait keselarasan bisnis dan TI. Semakin tinggi nilai rerata skala Likert, menunjukkan bahwa bisnis atau organisasi tersebut semakin matang dalam penyelarasan bisnis dan TI. Level kematangan tersebut dapat dilihat pada tabel 2.

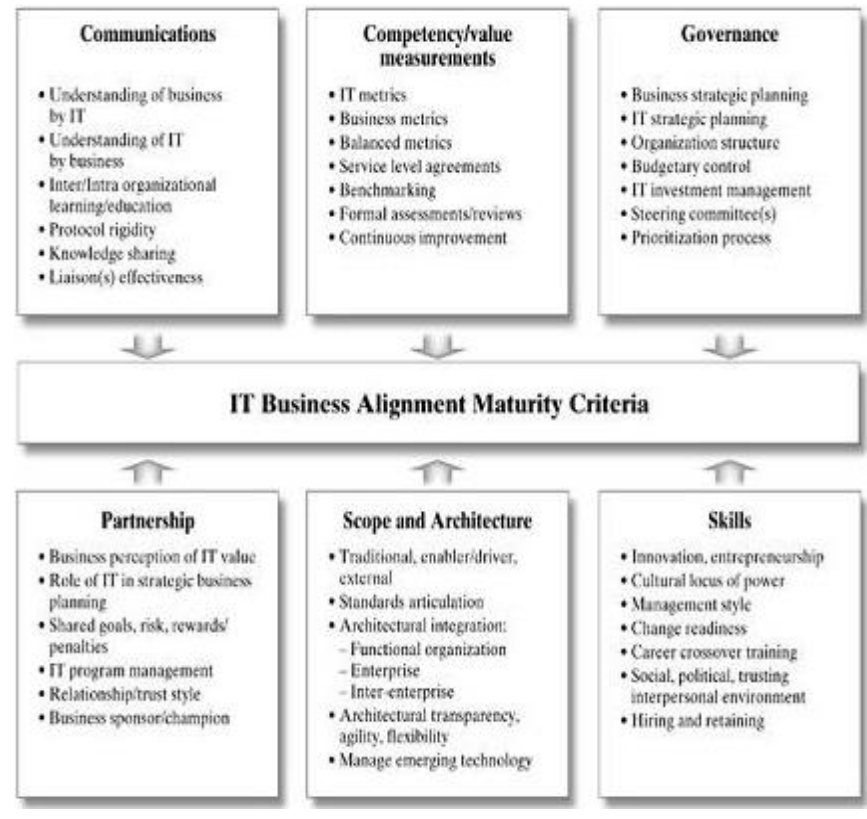

Gambar 2. Strategic Alignment Maturity Model. 
Tabel 2. Level Kematangan Keselarasan Bisnis \& TI.

\begin{tabular}{llc}
\hline & Level & Rentang Skala Likert \\
\cline { 3 - 3 } & & Rerata \\
\hline Level 1 & Initial & $1,0-1,99$ \\
\hline Level 2 & Committed & $2,0-2,99$ \\
\hline Level 3 & Established & $3,0-3,59$ \\
\hline Level 4 & Improved & $3,6-4,5$ \\
\hline Level 5 & Optimized & $>4,5$ \\
\hline
\end{tabular}

\section{B. Chief Information Officer (CIO)}

Di dalam sebuah organisasi, pemimpin merupakan salah satu unsur penentu dalam keberhasilan suatu organisasi. Pemimpin adalah seorang yang diharapkan mempunyai kemampuan untuk mempengaruhi, memberi petunjuk dan juga mampu menentukan individu untuk mencapai tujuan organisasi [7]. Dan bagi organisasi atau perusahaan besar yang memiliki ketergantungan bahkan menjadikan TI sebagai tulang punggung dalam bisnisnya, lazim jika memiliki manajer senior atau manajer eksekutif dalam bidang TI. Posisi ini dikenal dengan nama Chief Information Officer (CIO).

Terdapat berbagai alasan yang menyatakan tentang definisi dan kedudukan CIO. Salah satu pendapat menyatakan, bahwa CIO diciptakan untuk menetapkan akuntabilitas kepada satu eksekutif yang bertanggung jawab terhadap kebutuhan pengolahan informasi organisasi. Sedangkan yang lain menyatakan, bahwa posisi CIO ditujukan untuk menutup celah antara strategi bisnis dan TI. Dan di dalam sebuah perusahaan, baik perusahaan besar ataupun kecil, kedudukan CIO merupakan jabatan eksekutif dengan fokus utama kepada bisnis dan kemudian pada teknologi [8]. Dengan menempatkan CIO dalam tingkatan manajerial (eksekutif), dan kemampuan yang sesuai dengan organisasi, diharapkan dapat mengatasi tantangan dalam penyelarasan TI [3]. Adapun secara umum ada lima fungsi utama CIO dalam bisnis yaitu [7]:

1) Memahami Bisnis

2) Membangun Citra Divisi

3) Meningkatkan Mutu Penggunaan Teknologi

4) Visi Teknologi Informasi

5) Pengembangan Sistem Informasi

Peran CIO sebagai pengatur strategi teknologi bisnis, muncul sebagai bagian dari kekuasaan formal yang dimiliki CIO dan kemampuannya menyerap dan menyebarluaskan informasi yang relevan. Sedangkan untuk menciptakan keunggulan kompetitif berbasiskan TI, maka perusahaan membutuhkan CIO yang memiliki pendekatan strategi teknologi dari dalam dan keluar. Dan untuk menjamin efektivitas pelaksanaannya, CIO harus memiliki orientasi yang kuat terhadap informasi dan memiliki pengaruh yang kuat dalam perusahaan [9].

\section{METODOLOGI}

Tulisan ini disusun melalui kajian pustaka atau dokumen terkait dengan penyelarasan strategi bisnis dan TI ataupun materi lain yang relevan, dengan menggunakan berbagai data sekunder. Data tersebut meliputi hasil penelitian, studi kasus, jurnal ilmiah dan berbagai dokumen lain, baik dari media internet ataupun cetak. Tulisan ini tidak bertujuan menguji hipotesis atau membuktikan keabsahan suatu teori.

\section{PEMBAHASAN}

Dalam strategi SI/TI terintegrasi dengan strategi bisnis perusahaan. Strategi SI mendefinisikan kebutuhan bisnis terhadap SI dalam rangka mendukung strategi bisnis. Sedangkan strategi TI mendefinisikan bagaimana teknologi dapat menyediakan kebutuhan bisnis terhadap SI. Singkatnya, strategi SI berkaitan erat dengan bisnis dan kebutuhan bisnis, adapun strategi TI berkaitan erat dengan infrastruktur, sumber daya dan layanan TI kepada pengguna.

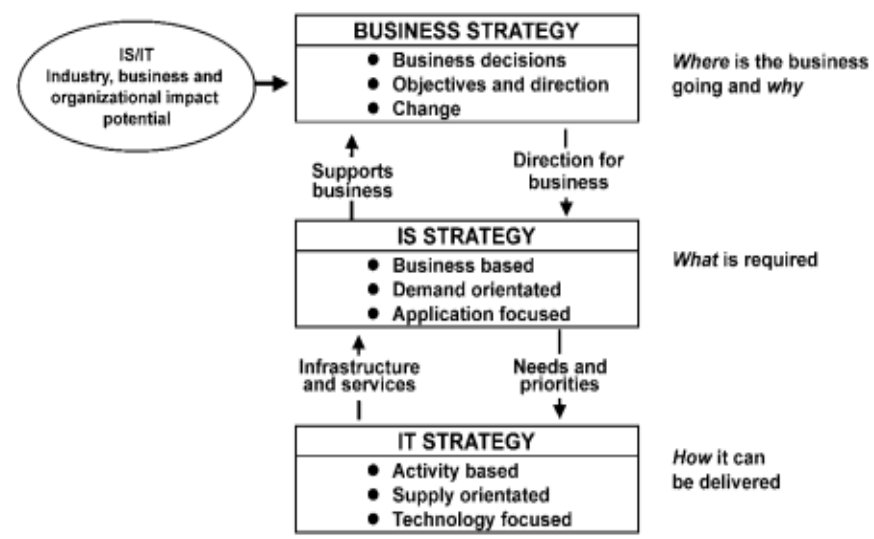

Gambar 3. Hubungan Antara Strategi Bisnis, Strategi SI Dan Strategi TI.

Sebuah studi menjelaskan, bahwa strategi TI diadopsi oleh komite eksekutif atau para pemimpin bisnis. Dalam sebuah hubungan yang harmonis dan komunikasi berjalan dengan baik, maka strategi bisnis dan TI akan saling mendukung. Hal tersebut dapat dijelaskan pada gambar 4.

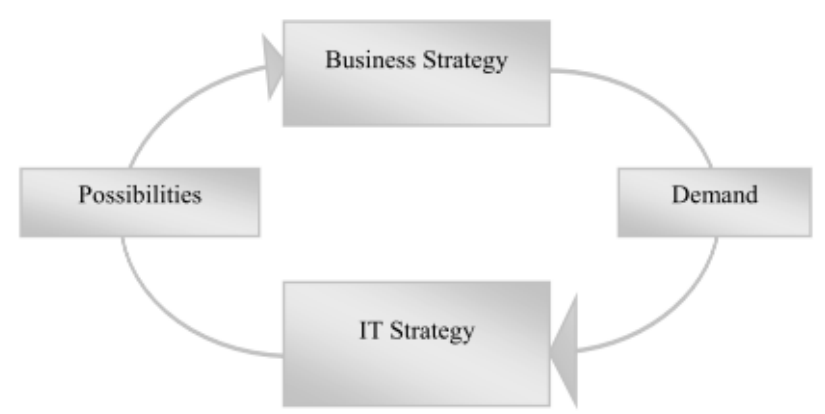

Gambar 4. Strategi TI Terhubung Dengan Strategi Bisnis.

Menyelaraskan strategi bisnis dan TI bukan sesuatu yang mudah dilakukan bagi sebuah organisasi dan tantangan yang dihadapi cukup besar dan berbeda pada tiap tingkatan organisasi. Relasi bisnis dan SI di dalam tiap tingkatan 
organisasi menunjukkan pola yang berbeda walaupun menggunakan pendekatan yang sama dalam menyelaraskan bisnis dan TI, dan relasi tersebut bersifat dinamis.

Terdapat empat hal yang perlu diperhatikan dalam melakukan penyelarasan strategi bisnis dan TI, yaitu: arahan yang jelas, komitmen, komunikasi dan integrasi antar fungsi [10]. Hal tersebut ditunjukan pada gambar 5.

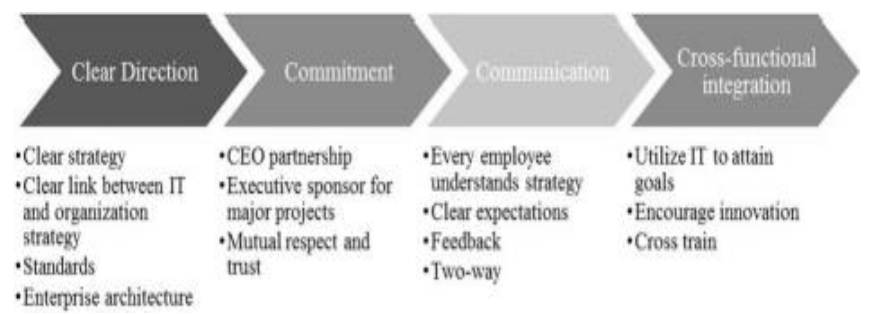

Gambar 5. Menuju Penyelarasan Strategi Bisnis dan TI.

Selain itu, terdapat enam hal penting sebagai pendukung dan penghambat dalam penyelarasan strategi bisnis dan TI, sesuai tabel 3 [5].

Tabel 3. Pendukung Dan Penghambat Keselarasan Strategi Bisnis Dan Strategi TI.

\begin{tabular}{ll}
\hline \multicolumn{1}{c}{ Enablers } & \multicolumn{1}{c}{ Inhibitors } \\
\hline $\begin{array}{l}\text { Senior Executive Support } \\
\text { For IT }\end{array}$ & $\begin{array}{l}\text { IT/Business Lack Close } \\
\text { Relationships }\end{array}$ \\
\hline $\begin{array}{l}\text { IT Involved In Strategy } \\
\text { Development }\end{array}$ & IT Does Not Prioritize Well \\
\hline IT Understands The & IT Fails To Meet Its \\
Business & Commitments \\
\hline Business - IT Partnership & IT Does Not Understand \\
& Business \\
\hline Well-Prioritized IT & Senior Executives Do Not \\
Projects & Support IT \\
\hline IT Demonstrates & IT Management Lacks \\
Leadership & Leadership \\
\hline
\end{tabular}

Data dalam tabel 3, menunjukkan bahwa dukungan eksekutif senior TI merupakan faktor pendukung dan juga penghambat dalam penyelarasan strategi bisnis dan TI. Dan dalam kaitan tersebut, CIO merupakan figur yang sangat berperan dalam suksesnya penyelarasan strategi bisnis dan TI. Eksekutif juga bertanggung jawab untuk meminimalkan berbagai faktor yang menghambat keselarasan bisnis dan TI, dan memaksimalkan hal yang mendukung.
Hasil penelitian menunjukkan Error! Reference source not found., CIO merupakan pemimpin transformasi yang menentukan solusi bisnis sebagaimana solusi teknologi bagi perusahaan. Peran lain dari CIO sebagai pemimpin transformasi, yaitu:

1) Leverage

CIO harus mengoptimalkan, menumbuhkan asas TI dan meningkatkan efisiensi proses perusahaan.

2) Expand

CIO harus memiliki fokus yang kuat pada pelebaran sayap perusahaan pada teknologi yang memungkinkan mencapai integrasi dan keefektifan yang paling tinggi.

3) Pioneer

CIO harus mengoptimalkan TI untuk mengubah produk, pasar dan model bisnis.

Selain itu, pemimpin dan profesional TI (CIO) harus memiliki kemampuan, sebagai [8] :

1) Risk Manager

CIO harus mampu memahami, berkomunikasi dan berbagi resiko proyek bisnis/TI dengan pelanggan atau pengguna.

2) Stakeholder Manager

CIO harus mampu membaca kondisi lingkungan yang kompleks dengan cepat dan menentukan faktor pendukung dan penghalang dari berbagai inisiatif. Serta mampu menyusun strategi dan memberikan pilihan bagi yang membutuhkan.

3) Change Agents

CIO harus mampu berinisiatif, memobilisasi dan melibatkan stakeholder internal dan eksternal perusahaan pada proyek penting.

Penelitian juga menyebutkan, bahwa Chief Executive Officer (CEO) memberikan mandat yang jelas untuk memperkuat kedudukan CIO. Dan CIO diharapkan menggunakan pengaruhnya tidak hanya pada proyek SI/TI, tapi pada cakupan yang lebih luas. Selain itu, penting juga bagi CIO untuk memahasi sifat dan penggunaan pengaruh yang dimilikinya dalam organisasi. Sehingga, dengan pengaruhnya yang baik, berpotensi dapat lebih efektif dalam upaya perencanaan strategi SI, implementasi SI dan perencanaan strategi bisnis.

Sedangkan berdasarkan prioritas aktivitas CIO, maka aktivitas terkait dengan strategi bisnis dan TI mendapatkan prioritas yang sebanding. Hal tersebut dapat dilihat pada tabel 6 .

\begin{tabular}{lccccccccccc}
\hline & $\mathbf{2 0 0 5}$ & $\mathbf{2 0 0 6}$ & $\mathbf{2 0 0 7}$ & $\mathbf{2 0 0 8}$ & $\mathbf{2 0 0 9}$ & $\mathbf{2 0 1 0}$ & $\mathbf{2 0 1 1}$ & $\mathbf{2 0 1 2}$ & $\mathbf{2 0 1 3}$ & $\mathbf{2 0 1 4}$ & AVG \\
\hline CEO & $43 \%$ & $45 \%$ & $31 \%$ & $43 \%$ & $46 \%$ & $44 \%$ & $49 \%$ & $43 \%$ & $44.7 \%$ & $44.2 \%$ & $43 \%$ \\
\hline $\boldsymbol{C F O}$ & $22 \%$ & $25 \%$ & $29 \%$ & $28 \%$ & $24 \%$ & $31 \%$ & $32 \%$ & $27 \%$ & $27.1 \%$ & $25.7 \%$ & $27 \%$ \\
\hline COO & $21 \%$ & $16 \%$ & $22 \%$ & $14 \%$ & $11 \%$ & $11 \%$ & $12 \%$ & $19 \%$ & $14.4 \%$ & $15.0 \%$ & $16 \%$ \\
$\begin{array}{l}\text { Business Executive } \\
\text { Unit }\end{array}$ & $6 \%$ & $9 \%$ & $7 \%$ & $3 \%$ & $9 \%$ & $4 \%$ & $5 \%$ & $10 \%$ & $9.2 \%$ & $9.4 \%$ & $7 \%$ \\
\hline \begin{tabular}{l} 
Other \\
\hline
\end{tabular} & $9 \%$ & $5 \%$ & $10 \%$ & $12 \%$ & $7 \%$ & $10 \%$ & $2 \%$ & $2 \%$ & $4.6 \%$ & $5.8 \%$ & $7 \%$ \\
\hline
\end{tabular}

Tabel 4. Kepada Siapa CIO Melapor. 
Tabel 5. Keterlibatan CIO dalam Keputusan Strategis.

\begin{tabular}{|c|c|c|c|c|c|c|c|}
\hline & $\begin{array}{c}\text { Strongly } \\
\text { Disagree }= \\
1\end{array}$ & $\begin{array}{c}\text { Disagree } \\
=2\end{array}$ & $\begin{array}{l}\text { Neither Agree } \\
\text { nor Disagree } \\
=3\end{array}$ & $\begin{array}{c}\text { Agree } \\
=4\end{array}$ & $\begin{array}{c}\text { Strongly } \\
\text { Agree }= \\
5\end{array}$ & $\begin{array}{c}\text { Don't } \\
\text { Know or } \\
\text { N/A }\end{array}$ & $A V G$ \\
\hline $\begin{array}{l}\text { I am on the top management } \\
\text { team that makes strategic } \\
\text { business decisions }\end{array}$ & $4.7 \%$ & $9.1 \%$ & $8.8 \%$ & $21.4 \%$ & $55.2 \%$ & $0.8 \%$ & 4.14 \\
\hline
\end{tabular}

Tabel 6. Aktivitas Utama CIO.

\begin{tabular}{|c|c|c|}
\hline \multirow[t]{2}{*}{ Activities Performed by CIOs } & \multicolumn{2}{|c|}{$\begin{array}{c}\text { Selecting an Activity } \\
\text { (standardized to } \\
100 \% \text { ) }\end{array}$} \\
\hline & TI & Bisnis \\
\hline $\begin{array}{l}\text { Business priorities, strategy, } \\
\text { architecture }\end{array}$ & & $8.1 \%$ \\
\hline IT priorities/strategy & $8.0 \%$ & \\
\hline Managing organizational change & & $6.8 \%$ \\
\hline Non IT related activities & & $5.1 \%$ \\
\hline Evangelist for the business & & $4.8 \%$ \\
\hline Business research & & $5.1 \%$ \\
\hline IT evangelist & $5.9 \%$ & \\
\hline IT governance & $5.4 \%$ & \\
\hline $\begin{array}{l}\text { IT human resources and talent } \\
\text { management }\end{array}$ & $4.7 \%$ & \\
\hline IT operation/facilities management & $5.1 \%$ & \\
\hline Knowing the needs of IT customers & & $6.6 \%$ \\
\hline $\begin{array}{l}\text { Knowing the needs of IT customers } \\
\text { of the business }\end{array}$ & & $6.5 \%$ \\
\hline Project management & $6.7 \%$ & \\
\hline Software management & $4.1 \%$ & \\
\hline Technical research & $5.9 \%$ & \\
\hline Resource allocation/budgeting & $6.0 \%$ & \\
\hline
\end{tabular}

Atasan dan kepada siapa CIO melapor, menunjukkan peran seorang CIO. Hasil penelitian pada tabel 4 dan tabel 5 menunjukkan bahwa CIO menduduki posisi strategis dalam organisasi dan dapat mengambil keputusan strategis. Selain itu, dalam tabel 7 menunjukkan bahwa CIO tidak hanya berinteraksi dengan atasannya secara langsung, tetapi CIO juga berinteraksi secara intensif dengan jajaran eksekutif yang lain untuk menjamin keselarasan strategi bisnis dan TI.

Tabel 7. Frekuensi CIO Berkomunikasi dengan Eksekutif Lain.

\begin{tabular}{lcccccc}
\hline & CEO & COO & CFO & CMO & CLO & Board \\
\hline Daily & $16.6 \%$ & $30.5 \%$ & $30.7 \%$ & $14.1 \%$ & $5.2 \%$ & $1.1 \%$ \\
\hline Weekly & $46.4 \%$ & $36.5 \%$ & $51.9 \%$ & $37.4 \%$ & $30.9 \%$ & $5.7 \%$ \\
\hline Monthly & $24.9 \%$ & $10.2 \%$ & $11.3 \%$ & $19.6 \%$ & $25.3 \%$ & $14.3 \%$ \\
\hline Quarterly & $6.9 \%$ & $2.3 \%$ & $2.1 \%$ & $3.7 \%$ & $12.3 \%$ & $28.3 \%$ \\
\hline Annually & $3.1 \%$ & $1.1 \%$ & $1.4 \%$ & $2.2 \%$ & $4.5 \%$ & $16.8 \%$ \\
\hline None & $2.1 \%$ & $19.5 \%$ & $2.5 \%$ & $23.0 \%$ & $21.9 \%$ & $33.7 \%$ \\
\hline
\end{tabular}

Sedangkan penilaian CIO berdasarkan aspek kemampuan, hasil penelitian menunjukkan bahwa aspek kepemimpinan, pengelolaan sumber daya manusia dan perencanaan strategis adalah kemampuan utama yang harus dimiliki seorang CIO.

Tabel 8. Kemampuan Utama dari CIO.

\begin{tabular}{|c|c|c|}
\hline \multirow[b]{2}{*}{ Skills (Sorted by CIO Rankings) } & \multicolumn{2}{|c|}{ CIO } \\
\hline & Rank & $\begin{array}{c}\% \\
\text { Selecting }\end{array}$ \\
\hline Providing leadership & 1 & $34.3 \%$ \\
\hline People management/relationships & 2 & $29.5 \%$ \\
\hline Strategic planning & 3 & $23.7 \%$ \\
\hline Decision making & 4 & $23.4 \%$ \\
\hline Communication (oral) & 5 & $20.8 \%$ \\
\hline $\begin{array}{l}\text { Collaboration with } \\
\text { others/teamwork }\end{array}$ & 6 & $20.2 \%$ \\
\hline Problem solving & 15 & $6.1 \%$ \\
\hline Technical knowledge & 22 & $2.6 \%$ \\
\hline Functional area knowledge & 25 & $2.2 \%$ \\
\hline
\end{tabular}

\section{KESIMPULAN}

Keselarasan bisnis dan TI merupakan hal yang sangat penting dan menjadi perhatian manajemen TI. Keselarasan bisnis dan TI merupakan suatu keharusan bagi organisasi untuk tetap dapat bertahan dan menjadi pemenang dalam persaingan global yang sangat sengit dan dinamis. Dan salah satu faktor penting ditentukan oleh kepemimpinan CIO dalam organisasi tersebut.

CIO harus menguasai strategi bisnis sama baiknya dengan penguasaannya terhadap TI. Dan dengan posisinya yang stategis dalam jajaran eksekutif, CIO memiliki visibilitas lebih luas terkait dengan strategi bisnis dan terlibat dalam pengambilan keputusan-keputusan besar terkait dengan bisnis. Hal ini dapat mempermudah $\mathrm{CIO}$ dalam menyelaraskan strategi bisnis dan TI.

\section{REFERENSI}

[1] IDC. (2016). Worldwide IT Spending Forecast to Reach $\$ 2.7$ Trilion in 2020 Led by Financial Services, Manufacturing, and Healthcare, According to IDC. The Worldwide Semiannual IT Spending Guide: Industry and Company Size.

[2] Ward, J. and Peppard, J. (2002) Strategic Planning for Information Systems, Third Edition. Canada: John Wiley \& Sons, Canada. 
[3] Coertze, J and Solms, V.R. The Board and CIO: The IT Alignment Challenge". Hawaii International Conference on System Sciences (HICSS), DOI: 10.1109/HICSS.2014.545. 2014.

[4] Kappelman, L., McLean, McLean, E., Johnson, V., Gerhart, N. (2014). The 2014 SIM IT Key Issues and Trends Study. MIS Quarterly Executive (13:4).

[5] Luftman, J., Papp, R., Brier, T. (1999). Enablers and Inhibitors of Business-IT Alignment, Commun AIS, vol. 1 , no. 3 es.

[6] Luftman, J. (2004). Managing the Information Technology Resources. New Jersey: Pearson Prentice Hall.

[7] Sprague and Barbara, C. M. N. (1993). Information Systems Management in Practice. New Jersey: PrenticeHall, Inc.
[8] Weiss, J.W. and Anderson Jr, D. (2003). CIO and IT Professionals as Change Agent, Risk and Stakeholder Manager: A Field Study. Proceedings of the $36^{\text {th }}$ Annual Hawaii International Conference on System Sciences.

[9] Carter, M., Grover, V. and Bennett, R. (2011). The Emerging CIO Role of Business Technology Strategist, MIS Quarterly Executive (10:1), 2011, pp. 19-29.

[10] Weiss, J.W. and Anderson Jr, D. (2004). Aligning Technology and Business Strategy: Issues \& Frameworks, A field study of 15 Companies. Proceedings of the $37^{\text {th }}$ Annual Hawaii International Conference on System Sciences, p. 10. 